Journal of Extension Education

Vol. 28 No. 3, 2016

DOI:https: / /doi.org/10.26725/JEE.2016.3.28.5680-5687

\title{
Exploring the Psychological Antecedents of Attitude towards Indigenous Wetland Practices
}

\section{N. Jayakumar ${ }^{1}$, M.Sundaramari ${ }^{2}$ and D.Puthira Prathap ${ }^{3}$}

\begin{abstract}
A study was conducted in the North eastern agro-climatic zone of Tamil Nadu, India to analyze the possible impact of the psychological antecedents of attitude towards Indigenous Wetland Practices(IWPs) among the farming community. Two hundred and nine farmers were selected at random from ten blocks in three districts of the state. Their psychological characteristics and attitude towards IWPs were assessed. The mean attitude score and the mean attitude index were analysed. The highest variable index was found in the case of Progressivism and Traditionalism, followed by Self-Reliance. Environmental orientation and Decision making ability had a positive and highly significant relationship while Scientific Orientation had a negative and highly significant relationship with attitude towards Indigenous Wetland Practices.
\end{abstract}

Keywords : Indigenous Wetland Practices, Psychological antecedents, Attitude, India

\section{INTRODUCTION}

Global research efforts, through biological technologies and other methods helped in increasing crop yields, resulting in substantial increase in food production in developing countries and in turn commercialized the process of agriculture. However, the intensive use of land, fertilizers, pesticides and irrigation had negative impacts on the environment and human health. Stakeholders in agriculture are at a crossroads of balancing the increasing food requirements with limited damage to the environment. Of late, sustainability issues have infused sanity in utilising interventions without much damage to the environment. The need for organic agriculture and use of eco-friendly technologies to increase productivity in order to feed the increasing population is the results of such thoughts.

Recent researches have aimed at documenting, rationalising, and blending the Indigenous Knowledge with the so called Scientific or Western knowledge so as to take care of the sustainability issues. Indigenous knowledge (IK) is the sum total of knowledge and practices that are based on peoples accumulated

1. Ph.D.Scholar and 2.Professor (Agricultural Extension), Faculty of Agriculture and Animal Husbandry, Gandhigram Rural Institute, Gandhigram - 624302 and 3. Principal Scientist (Agricultural Extension), ICAR-Sugarcane Breeding Institute, Coimbatore - 641007 
experience in dealing with situations and problems in various aspects of life and such knowledge and practices are special for a particular culture (Wang, 1988).This pool of knowledge is fast expanding and efforts are being taken to popularise these knowledge among the farming community. In spite of these efforts, many of these documented practices are not that popular and many times are confined to the knowledge of few, presently called organic farmers or erstwhile traditional farmers (Jayakumar \& Sundaramari, 2014). Keeping this in mind, the study was conducted with the following objectives:

- To study the attitude of the farmers towards Indigenous Wetland Practices (IWPs).

- To analyse the psychological antecedents and their possible influence on the attitude towards Indigenous Wetland Practices.

\section{METHODOLOGY}

The present study was carried out in the north eastern agro climatic zone of Tamil Nadu, a constituent state of India. Ten blocks with large area under rice cultivation were purposively selected from Kancheepuram, Thiruvallur and Tiruvannamalai districts. A list of all the villages in these ten blocks was prepared and twenty villages were selected from the list using the random number table. A total of 209 farmers selected at random from these villages were interviewed for the study. The attitude of the farmers towards Indigenous Wetland Practices was studied using a scale developed by Venkatesan (2014) with a slight modification. In order to study the mind-set of the farmers, psychological antecedents namely, Scientific orientation(Sundaramari, 2001), Progressivism - Traditionalism (Venkatesan, 2014), Environmental Orientation(Jayawardana, 2007), Innovativeness(Devi 2003), Self Reliance(Marimuthu, 2001), Economic Orientation(Marimuthu, 2001) and Decision Making Ability (Parimaladevi, 2004) were used. The psychological antecedents were compared using Mean and Standard deviation. The mean indices for each variable was worked out and the Mean Psychological Antecedent Index (MPAI) was obtained. Correlates for the above variables were made for meaningful interpretation.

\section{FINDINGS AND DISCUSSION}

\section{Attitude towards Indigenous Wetland Practices}

Attitude is a predisposition or a tendency to respond positively or negatively towards a certain idea, object, person, or situation. Attitude influences an individual's choice of action, and responses to challenges, incentives, and rewards. The acceptance of a technology or practice among the farming community is influenced by the attitude of the farmers towards them. The attitude scale had twenty items of which ten were positive statements 
and ten were negative statements. The maximum score that was possible was 60. It was found that the mean score obtained was 45.42. The mean attitude index was found to be 75.70 which is a welcome trend. Moreover it was found that 55.00 per cent of the respondents scored above the mean value. This shows a favourable attitude towards Indigenous wetland practices among the farmers. These findings are in accordance with the results reported by Sakeerhusain (2010).

The scale items were ranked (Table 1) to know which were more agreed upon by the farming community. It was found that "IWPs are environmentally friendly" was agreed by a majority of the farmers with the highest ranking. "Indigenous Wetland Practiceshave high adaptability to the local areas" was the second highest agreed item followed by "Indigenous Wetland Practices are locally available". "Indigenous Wetland Practices are very simple and easy to understand and practice" was the fourth ranked one on the list.

It could be seen that all these items were ranked higher possibly due to the reason that they all dealt with availability and being local. Moreover they were easy to use and environmental friendly. This supports the views of Bhople \& Darbha(2000).

Table 1.

Ranking the Scale Items of IWPs

\begin{tabular}{|c|l|c|}
\hline $\begin{array}{c}\text { S1. } \\
\text { No. }\end{array}$ & \multicolumn{1}{|c|}{ Scale items } & Rank \\
\hline 1. & Indigenous Wetland Practices are environment friendly & $\mathbf{1}$ \\
\hline 2. & Indigenous Wetland Practices are efficient in solving farmers problems & $\mathbf{1 1}$ \\
\hline 3. & Indigenous Wetland Practices have scientific or other rationale & $\mathbf{1 0}$ \\
\hline 4. & $\begin{array}{l}\text { Indigenous Wetland Practices are very simple and easy to understand } \\
\text { and practice }\end{array}$ & $\mathbf{4}$ \\
\hline 5. & Use of Indigenous Wetland Practices in farming reduces risks & $\mathbf{6}$ \\
\hline 6. & $\begin{array}{l}\text { Availability of input will not be a problem in using Indigenous Wetland } \\
\text { Practices. }\end{array}$ & $\mathbf{5}$ \\
\hline 7. & $\begin{array}{l}\text { Indigenous Wetland Practices are supplementary and complementary } \\
\text { to modern technologies in agriculture }\end{array}$ & $\mathbf{7}$ \\
\hline 8. & $\begin{array}{l}\text { Indigenous Wetland Practices have high adaptability to the local } \\
\text { areas. }\end{array}$ & $\mathbf{2}$ \\
\hline
\end{tabular}




\begin{tabular}{|c|c|c|}
\hline 9. & $\begin{array}{l}\text { Indigenous Wetland Practices are economical as the cost of the inputs } \\
\text { requires is very low }\end{array}$ & 8 \\
\hline 10. & Indigenous Wetland Practices are locally available & 3 \\
\hline 11. & Indigenous knowledge does not lead to high productivity & 16 \\
\hline 12. & Indigenous Wetland Practices are outdated & 15 \\
\hline 13. & $\begin{array}{l}\text { Indigenous Wetland Practices are baseless and short of any scientific } \\
\text { evidence. }\end{array}$ & 13 \\
\hline 14. & $\begin{array}{l}\text { It is unwise to use Indigenous Wetland Practicesin agriculture, as it } \\
\text { does not guarantee for success }\end{array}$ & 14 \\
\hline 15. & Indigenous Wetland Practices are superstitious & 9 \\
\hline 16. & $\begin{array}{l}\text { Farmers should not use Indigenous Wetland Practices to have better } \\
\text { yield and profit. }\end{array}$ & 12 \\
\hline 17. & $\begin{array}{l}\text { A farmer should not adopt Indigenous Wetland Practices when there } \\
\text { are proven alternate scientific technologies. }\end{array}$ & 18 \\
\hline 18. & Indigenous Wetland Practices are inferior to modern technologies. & 19 \\
\hline 19. & $\begin{array}{l}\text { Indigenous Wetland Practices in agriculture are not sustainable on } \\
\text { a long term basis. }\end{array}$ & 17 \\
\hline 20. & $\begin{array}{l}\text { It is difficult for a farmer to shift from modern ways of cultivation to } \\
\text { indigenous ways of cultivation. }\end{array}$ & 20 \\
\hline
\end{tabular}

The items with the last four ranks revealed that farmers accepted that Indigenous Wetland Practices were not sustainable, inferior to modern technologies and the shift from modern ways to indigenous ways were difficult. Though there was an increased awareness about environment friendly nature, easy and local availability of wetland practices when it comes to putting into practice, modern ways had higher preferences compared to Indigenous Wetland Practices.

\section{Comparison of the Psychological Antecedents}

The Mean Psychological Antecedent Index was found to be 74.72 which is an appreciable value. This implies that majority of the farmers were higher on an overall basis. The highest 
variable index was found in the case of Progressivism and Traditionalism with 90.33 followed by Self- Reliance with 82.33. Progressivism -Traditionalism referred to the relative receptivity of the farmer towards modern values and practices. Self-reliance is related to fiscal orientation and planning. Better educational levels and exposure to mass media might have helped in ranking these variables higher. The mean score for Progressivism and Traditionalism was 8.13 out of the maximum possible value of 9 and 61.24 per cent of the respondents were above the mean score. In the case of Self - Reliance, the mean score was 2.47 out of 3 and 50.72 per cent of the respondents had obtained a score above the mean value.

Environmental orientation and Decision making ability with 74.66 and 73.40 were the next to follow. Environmental orientation is the degree to which a farmer is concerned about the environment. Decision making ability is the ability of the respondents to select the most efficient means from among the available alternatives without depending on others.

In case of variables viz., Scientific orientation, Innovativeness and Economic orientation, the indices were found to be above 65.00. Scientific orientation is the degree to which a farmer is oriented towards the use of scientific method of farming, while Innovativeness is defined as the degree to which an individual is relatively earlier in adopting new ideas than other members of the social system. Economic orientation is the profit maximization and the relative value placed by farmers on economic needs. In the case of Scientific orientation the mean score was 27.83 out of 42 and 54.55 per cent of the respondents were above the mean value. Similar was the case with Economic orientation (27.91 out of 42 and 52.63 above the mean score).

Table 2.

Comparison of the Psychological Antecedents

\begin{tabular}{|c|c|c|c|c|c|c|c|}
\hline \multirow{2}{*}{$\begin{array}{l}\text { S1. } \\
\text { No. }\end{array}$} & \multirow{2}{*}{$\begin{array}{c}\text { Psychological } \\
\text { variables }\end{array}$} & \multirow{2}{*}{$\begin{array}{c}\text { Maximum } \\
\text { possible } \\
\text { score }\end{array}$} & \multirow{2}{*}{$\begin{array}{c}\text { Mean } \\
\text { score } \\
\text { obtained }\end{array}$} & \multirow{2}{*}{$\begin{array}{c}\text { Mean } \\
\text { variable } \\
\text { index }\end{array}$} & \multirow{2}{*}{$\begin{array}{l}\text { Standard } \\
\text { deviation }\end{array}$} & \multicolumn{2}{|c|}{$\begin{array}{c}\text { Respondents } \\
\text { above the } \\
\text { mean score }\end{array}$} \\
\hline & & & & & & Freq. & $\begin{array}{c}\text { Per } \\
\text { cent }\end{array}$ \\
\hline 1. & $\begin{array}{l}\text { Scientific } \\
\text { orientation }\end{array}$ & 42 & 27.83 & 66.26 & 4.772 & 114 & 54.55 \\
\hline 2. & $\begin{array}{l}\text { Progressivism - } \\
\text { Traditionalism }\end{array}$ & 9 & 8.13 & 90.33 & 1.172 & 128 & 61.24 \\
\hline 3. & $\begin{array}{l}\text { Environmental } \\
\text { Orientation }\end{array}$ & 6 & 4.48 & 74.66 & 1.173 & 95 & 45.45 \\
\hline
\end{tabular}


Journal of Extension Education

\begin{tabular}{|c|l|c|c|c|c|cr|}
\hline 4. & Innovativeness & 3 & 2.08 & 69.33 & 0.703 & 60 & 28.71 \\
\hline 5. & Self - Reliance & 3 & 2.47 & 82.33 & 0.564 & 106 & 50.72 \\
\hline 6. & $\begin{array}{l}\text { Economic } \\
\text { Orientation }\end{array}$ & 42 & 27.91 & 66.45 & 3.397 & 110 & 52.63 \\
\hline 7. & $\begin{array}{l}\text { Decision } \\
\text { Making Ability }\end{array}$ & 24 & 17.69 & 73.70 & 2.819 & 99 & 47.37 \\
\hline & \multicolumn{3}{|l|}{ Mean Psychological Antecedent Index } & \multicolumn{3}{|c|}{74.72} \\
\hline
\end{tabular}

Influence of Psychological Antecedents on Attitude towards IWPs

It was found that Environmental orientation and Decision making ability had a positive relationship with attitude towards Indigenous Wetland Practices (Table 3). They were found to be highly significant at $1 \%$ level of significance. The Indigenous Wetland Practices are considered environmentally safe and possibly this might be the reason why environmental orientation had a positive and highly significant relationship with attitude towards IWPs. When it comes to choosing the best available option, a farmer may consider the availability, cost, ease in use and its possible impact on the environment. IWPs have been credited to be on a better position in all these factors. Possibly this might have been the reason why decision making ability had a highly significant relationship with attitude towards IWPs.

Table 3.

Correlation of Psychological antecedents with Attitude towards IWPs

\begin{tabular}{|c|l|c|}
\hline S1. No. & \multicolumn{1}{|c|}{ Psychological antecedents } & Correlation “r” value \\
\hline 1. & Scientific Orientation & $-0.205\left(^{(* *}\right)$ \\
\hline 2. & Progressivism Traditionalism & $-0.021 \mathrm{NS}$ \\
\hline 3. & Environmental Orientation & $0.255\left(^{* *}\right)$ \\
\hline 4. & Innovativeness & $-0.042 \mathrm{NS}$ \\
\hline 5. & Self-Reliance & $-0.004 \mathrm{NS}$ \\
\hline 6. & Economic Orientation & $-0.133 \mathrm{NS}$ \\
\hline 7. & Decision Making Ability & $0.229(* *)$ \\
\hline
\end{tabular}

** Correlation is significant at the 0.01 level. NS: Not significant 
Exploring the Psychological Antecedents of Attitude towards Indigenous Wetland Practices

Whereas Scientific Orientation had a negative and highly significant relationship with attitude towards Indigenous Wetland Practices $\left(-0.205^{* *}\right)$. This reveals that an increased scientific orientation will have a negative impact on attitude towards ITK. In most cases, being oriented towards scientific methods of farming means being obsessed with western methods of farming and naturally this will have a negative influence on the traditional farming practices, which are not that modern.

The other variables like Progressivism- Traditionalism, Innovativeness, Self - Reliance and Economic Orientation did not have significant influence on the dependent variable.

\section{CONCLUSION}

Attitude to some extent has an influence on action. In this study, the respondents had showed a favourable attitude towards IWPs. Environmental orientation and Decision making ability had a positive and highly significant relationship while Scientific Orientation had a negative and highly significant relationshipwith attitude towards Indigenous Wetland Practices. It could be concluded that there is an increased environmental concern. An increased decision making ability of the farmers might develop a favourable attitude towards IWPs, ultimately resulting in higher adoption of IWPs. Taking the findings of the study in to account, policy makers and academicians should see that natural resource management and sustainability options that are embedded in IWPs are effectively documented. This should eventually find a place in the current institutional training programmes being organized by the extension system for the farmers in the country.

\section{REFERENCES}

Bhople, R.S. \& Darbha, S. (2000). Indigenous grain storage practices adopted in rural households. Agricultural Extension Review, 12 (6), 26-29.

Devi, P.R. (2003). Micro credit and technology utilization in vegetable production by self-help groups in Thiruvananthapuram district, Unpublished M.Sc. (Ag.) thesis, Kerala Agricultural University, Thrissur, India $72 \mathrm{p}$.

Jayakumar, N. \& Sundaramari, M. (2014). Management Characteristics and Adoption Index of Indigenous Agricultural Practices by Rice Farmers, Journal of Extension Education, 26 (4). Retrievable from https:// extensioneducation.org/index.php/ jee/article/view/70

Jayawardana, J. K. J. P. (2007). Organic agricultural practices in coconut based homesteads in Thiruvananthapuram district. Unpublished M. Sc. (Ag.) thesis, Kerala Agricultural University, Thrissur, India, 124p. 
Marimuthu, P. (2001). Indigenous Tribal wisdom for rural development: A multidimensional analysis. Unpublished Ph.D. thesis, TNAU, Coimbatore.

Parimaladevi, S. (2004). Effectiveness of agriclinics and agribusiness training programme in Kerala. Unpublished M.Sc. (Ag.) thesis, Kerala Agricultural University, Thrissur, India, 85p.

Sakeerhusain, A. (2010). Knowledge, adoption and perceived effectiveness of indigenous horticultural practices in Kerala, Unpublished Ph.D. thesis, Gandhigram Rural Institute, Gandhigram, India.
Sundaramari, M. (2001). Adoption and perceived effectiveness of indigenous agricultural practices in different farming systems. Unpublished Ph.D.thesis, Gandhigram Rural Institute, Gandhigram, India.

Venkatesan. (2014). Adoption and Perceived Effectiveness of Indigenous Tribal Agricultural Practices of Kolli Hills, Tamilnadu. Unpublished Ph.D.thesis, Gandhigram Rural Institute, Gandhigram, India

Wang. (1988). Indigenous Communication Systems in Research and Development, Journal of Extension Systems, 4(2), $75-86$. 